\title{
Self assembled cationic cell penetrating peptide nanoparticles as efficient cargoes for antimicrobial agents
}

\author{
A Aravind, A Deepu, K Santhosh Kumar ${ }^{*}$ \\ From 2nd International Science Symposium on HIV and Infectious Diseases (HIV SCIENCE 2014) \\ Chennai, India. 30 January - 1 February 2014
}

\section{Background}

The development of technologies that enable bioactive molecules with low membrane permeability to effectively penetrate biological membranes is one of the greatest challenges in the pharmaceutical field. The HIV-1 transactivating transcriptor (TAT) peptide is one of the most widely used molecular beacons for drug delivery. Cationic antimicrobial peptides have received increasing attention due to their broad spectrum activities and ability to combat multi drug resistant microbes. Our aim is to develop cationic cell penetrating peptide nanoparticles which could efficiently deliver antimicrobial agents against infectious diseases.

\section{Methods}

The cationic TAT peptides were synthesized by Fmoc solid phase peptide synthesis and were purified by semi preparative RP-HPLC. The molecular mass of peptides was confirmed by MALDI TOF-MS. The purified peptides were modified into self assembled nanoparticles (micelles) and structural characterization was done by a particle size analyzer and TEM. The antimicrobial activity evaluation was done against both Gram positive and Gram negative bacterial strains.

\section{Results}

We have designed and synthesized arginine and lysine rich cationic TAT peptides and modified them into nanoparticles. These nanoparticles were structurally and functionally characterized. Some analogues of these nanoparticles cargoes showed significant antimicrobial activity against Gram positive and negative bacterial

\footnotetext{
* Correspondence: kskumar@rgcb.res.in

Chemical Biology Lab, Rajiv Gandhi Centre for Biotechnology,

Thiruvananthapuram, India
}

penetrating peptide nanoparticles as efficient cargoes for antimicrobial agents. BMC Infectious Diseases 2014 14(Suppl 3):P19.

Submit your next manuscript to BioMed Central and take full advantage of:

- Convenient online submission

- Thorough peer review

- No space constraints or color figure charges

- Immediate publication on acceptance

- Inclusion in PubMed, CAS, Scopus and Google Scholar

- Research which is freely available for redistribution
Cite this article as: Aravind et al.: Self assembled cationic cell 